\title{
PENGARUH SELF-SELECTED INDIVIDUAL MUSIC THERAPY (SeLIMUT) TERHADAP PERUBAHAN STATUS HEMODINAMIK PASIEN KANKER PALIATIF DI RSUP Dr. SARDJITO YOGYAKARTA
}

\author{
Dedi Kurniawan ${ }^{1}$, Sri Setiyarini ${ }^{2}$, Martina Sinta Kristanti ${ }^{3}$ \\ ${ }^{1}$ Kepanjen School of Health Science, Malang \\ ${ }^{2}$ Department of Nursing Sciences Faculty of Medicine, Gadjah Mada University Yogyakarta \\ ${ }^{3}$ Department of Nursing Sciences Faculty of Medicine, Gadjah Mada University Yogyakarta \\ E-mail : dedi.k@stikeskepanjen-pemkabmalang.ac.id
}

\begin{abstract}
The unstabled blood pressure and pulse rates of palliative care cancer patients were due to the psychological stressed, pain, and anxiety. Complementary And Alternative Medicine (CAM) have been apply to reduce the commons symptoms of advanced illness. The aim of this study was to explain the effect of SeLIMuT to hemodynamic palliative care cancer patients in dr. Sardjito Yogyakarta hospital. A quasi experiment pre-posttest with control group designed apply to this study. A purposive sampling technique carried out in IRNA I RSUP Dr. Sardjito Yogyakarta which were divided into two groups: the intervention and control group. The intervention group $(n=23)$ received 4 times SeLIMuT therapy for 2 days with each session about 15 to 20 minutes, and controlled group $(n=23)$ did not receive any therapies. Pre and post test measured of pulse rates and blood pressure. It was clinically significant if there was cut off point was $a \geq 10 \mathrm{mmHg}$ on both systolic and diastolic level and $>4 \mathrm{x} /$ minute on the pulse rates. Statistically, a significant mean values difference of systolic $(p=0,001)$, diastolic $(p=0.024)$ dan pulse rates $(p=0,001)$, as significanceas $p<0,05$. In addition, a decrease of $3,70 \mathrm{mmHg}$ on systole level, 2,18 $\mathrm{mmHg}$ on diastole level, dan 0,52 on pulse rate, however these values had no clinically significance based on both of cut-off point. The control group systolic level hadn't changed, which is the diastole level and pulse rates have been increased. Statistically, SeLIMUT has a positive effect on the hemodynamic status of patients with cancer taking palliative care, although there was not significance clinically.
\end{abstract}

\section{Keywords : Palliative cancer, Hemodynamic, SeLIMuT, Music Therapy}

\begin{abstract}
Abstrak : Ketidakstabilan tekanan darah dan denyut nadi pada pasien kanker paliatif dilaporkan lebih besar terjadi sebagai akibat reaksi psikologis nyeri dan kecemasan yang dialami. Complementary and Alternative Medicine (CAM) menjadi tren pilihan terapi untuk mengurangi gejala yang mengganggu pasien kanker paliatif. Penelitian ini bertujuan untuk mengetahui pengaruh SeLIMuT terhadap perubahan status hemodinamik pasien kanker paliatif. Quasi Experiment pre-test and post-test design with Comparison Group dengan purposive sampling yang dilakukan di IRNA I RSUP Dr. Sardjito Yogyakarta. Responden dibagi dalam kelompok intervensi $(n=23)$ menerima terapi SeLIMuT selama 4 kali dalam dua hari dengan durasi tiap terapi 15-20 menit dan kelompok kontrol $(n=23)$ tidak diberikan terapi. Kedua kelompok dilakukan pengukuran tekanan darah dan denyut nadi pre dan post. Dikatakan bermakna secara klinis jika perubahan sebesar $\geq 10 \mathrm{mmHg}$ pada sistolik dan diastolik dan $>4 \mathrm{x} /$ menit pada nadi. Hasil penelitian menunjukan bahwa terdapat perbedaan yang signifikan rerata sistolik $(p=0,001)$, diastolik $(p=0,024)$ dan denyut nadi $(p=0,001)$, signifikan jika $p<0,05$. Terjadi penurunan sebesar $3,70 \mathrm{mmHg}$ pada sistolik, 2,18 $\mathrm{mmHg}$, dan 0,52 pada nadi, namun penurunan tersebut tidak bermakna secara klinis. Perbedaan nilai sistolik pre-post pada kelompok kontrol cenderung tetap, sedangkan pada diastolik dan nadi justru menunjukkan peningkatan. Secara statistik SeLIMuT berpengaruh positif terhadap status hemodinamik pasien kanker paliatif, namun hasil tersebut tidak bermakna secara klinis.
\end{abstract}

Kata Kunci : Kanker paliatif, hemodinamik, SeLIMuT, terapi musik.

\section{PENDAHULUAN}

Kanker dikenal sebagai penyakit yang menakutkan karena memiliki prognosis yang buruk dan menjadi masalah kesehatan masyarakat, baik di Indonesia maupun di dunia (Kaliyaperumal \& Subash, 2010). Tingginya angka kematian karena kanker adalah karena $70 \%$ pasien yang datang ke rumah sakit pada stadium lanjut. Angka harapan kesembuhan kanker sangat kecil, pengobatan mungkin terus dilakukan tetapi bukan untuk mengobati penyakitnya melainkan hanya untuk mengurangi atau menghilangkan gejalanya (Smeltzer, 2002). Penyakit ini berakibat serius pada Quality of Life dimana pasien sering mengalami penderitaan fisik, psikososial, spiritual, dan berbagai masalah lain.

Masalah fisik yang paling sering menyertai penyakit kanker adalah nyeri, termasuk di Indonesia (Effendy., Engels., Osse., Bart., Tejawinata., Vissers., \& Vernooij-Dassen, 2011). Nyeri pada pasien 
kanker sering menimbulkan masalah psikologi yang menyebabkan stress baik bagi pasien maupun keluarga (Stanczyk, 2011). Pasien kanker sering mengalami masalah psikologi karena diagnosa kanker merupakan merupakan salah satu peristiwa paling menakutkan yang menyebabkan stress baik bagi pasien maupun keluarga (Thompson \& Grocke, 2007).

Reaksi psikologis terhadap nyeri yang distimulasi saraf simpatik erat hubungannya dengan peningkatan tekanan darah dan peningkatan frekuensi jantung yang merupakan komponen dari hemodinamik (Bernardi., Porta., \& Sleight, 2006). Pasien kanker yang tegang dan cemas akibat peningkatan tekanan darah dan frekuensi detak jantung lebih banyak merasakan nyeri selama perawatan berlangsung dibanding pasien yang rileks (Burns., Harbuz., Hucklebridge \& Bunt,2001).

Pentingnya pemantauan terus menerus terhadap status hemodinamik pada pasien kanker akan menjamin early detection bisa dilaksanakan dengan baik, membantu dalam mengetahui respon pasien terhadap intervensi dan terapi, serta sebagai indikator terhadap kondisi distress psikologis pasien kanker (Bernardi., Porta., \& Sleight, 2006). Trend perawatan paliatif saat ini adalah dengan menggabungkan terapi medis dengan terapi komplementer (Complementary and alternative medicine/CAM) untuk mengurangi gejala yang mengganggu pasien. Salah satu bentuk terapi komplementer itu adalah terapi musik (Burns., Harbuz., Hucklebridge \& Bunt,2001).

Terapi musik memiliki kelebihan yaitu merupakan intervensi yang dapat diterapkan secara sederhana, non invasif, tidak selalu membutuhkan kehadiran ahli terapi, serta harganya terjangkau dan tidak menimbulkan efek samping (Halim, 2007). Dipandang dari segi medis, musik memiliki efek yang menguntungkan terhadap tubuh dan psikis. Terapi musik memiliki tujuan untuk membantu pasien dalam mengekspresi-kan perasaan, membantu rehabilitasi fisik, memberi pengaruh positif terhadap kondisi suasana hati dan emosi, meningkatkan memori, serta menyediakan tempat yang unik untuk berinteraksi dan membangun kedekatan emosional (Purwanto., Sumarni., \& Sutono, 2008).
Musik juga digunakan untuk terapi gangguan mental, dan musik memiliki efek perawatan kecemasan dan depresi, dikatakan bahwa stimulus audio dengan musik dapat memberikan efek relaksasi dan analgesia (Djohan, 2010). Beberapa alasan yang telah dijelaskan di atas, menjadikan dasar penelitian untuk menawarkan inovasi baru Self - Selected Individual Music Therapy (SeLIMuT) di bidang kesehatan khususnya sebagai terapi komplementer yang memberikan efek relaksasi pasien kanker paliatif.

Terapi SeLIMuT adalah prosedur pemberian terapi musik yang mudah, murah, dan efektif dengan mendengarkan jenis musik slow tempo stabil, level suara rendah dan soft dynamic, tekstur konsisten (kombinasi suara dan instrumental). Terapi ini diberikan selama 15-20 menit dan memberikan kebebasan pasien untuk memilih musik yang disukai dan dikombinasikan dengan nafas dalam. Berdasarkan latar belakang tersebut, penulis tertarik melakukan penelitian untuk mengetahui pengaruh Self-selected Individual Music Therapy (SeLIMuT) terhadap tingkat nyeri pasien kanker paliatif di RSUP Dr. Sardjito Yogyakarta.

\section{METODE PENELITIAN}

Jenis penelitian intervensi dengan rancangan Quasi Experiment-pre-test and post-test design with Comparison Group. Dilakukan dua kali pengukuran variabel sistolik, diastolik dan denyut nadi (pre dan post test) pada kedua kelompok. Pengambilan data dilakukan pada bulan November-Desember 2012 di Instalasi Rawat Inap I (IRNA I) Rumah Sakit Umum Pusat (RSUP) Dr. Sardjito Yogyakarta. Sampel penelitian didapatkan menggunakan teknik purposive sampling dengan kriteria inklusi meliputi: pasien terdiagnosis kanker stadium III dan atau IV oleh dokter, berusia 18 tahun ke atas, tidak mengalami gangguan pendengaran, menyukai musik, dan bersedia terlibat dalam penelitian. Kriteria eksklusi meliputi: pasien yang mengalami penurunan kesadaran, pasien tidak kooperatif, dan pasien dalam keadaan emergency. Kriteria pasien yang mengalami drop out dalam penelitian adalah saat intervensi SeLIMUT berlangsung, pasien tiba-tiba mengalami 
keadaan emergency atau tidak kooperatif. Banyaknya sampel dalam penelitian ini adalah 46 orang yang dibagi dalam dua kelompok, kelompok SeLIMuT $(n=23)$ dan kelompok kontrol $(n=23)$. Pengukuran tekanan darah menggunakan alat spygmomanometer air raksa dan jam tangan untuk menghitung denyut nadi. Intervensi SeLIMuT diberikan empat kali selama dua hari melalui MP3 Player dan earphone. Setiap sesinya terapi berlangsung selama 15-20 menit. Sebelum

\section{HASIL PENELITIAN}

Data demografi responden kelompok SeLIMuT dan kontrol dibandingkan (Tabel 1). Hasil uji homogenitas data demografi pada kedua kelompok menunjukkan bahwa dan sesudah terapi, dilakukan pengukuran nyeri dan nafas dalam selama 1 menit. Data demografi responden pada kedua kelompok diuji secara univariat dan dilakukan uji homogenitas dengan Chi-square test atau Fisher's exact test untuk data kategorik dan data numerik diuji dengan independent $t$ test atau Mann-Whitney $U$ test. Nilai rerata sistolik dan diastolik kedua kelompok diuji menggunakan Mann-Whitney $U$ test sedangkan denyut nadi menggunakan uji $t$ test dengan $\alpha<0.05, \quad \mathrm{Cl} \quad 95 \%$.

tidak terdapat perbedaan yang signifikan pada kedua kelompok responden. Hal ini berarti karakteristik responden kedua kelompok adalah homogen atau sama.

Tabel 1. Karakteristik Demografi Responden Pasien Kanker Paliatif di IRNA I RSUP Dr. Sardjito Yogyakarta Bulan November 2012 ( $n=46)$

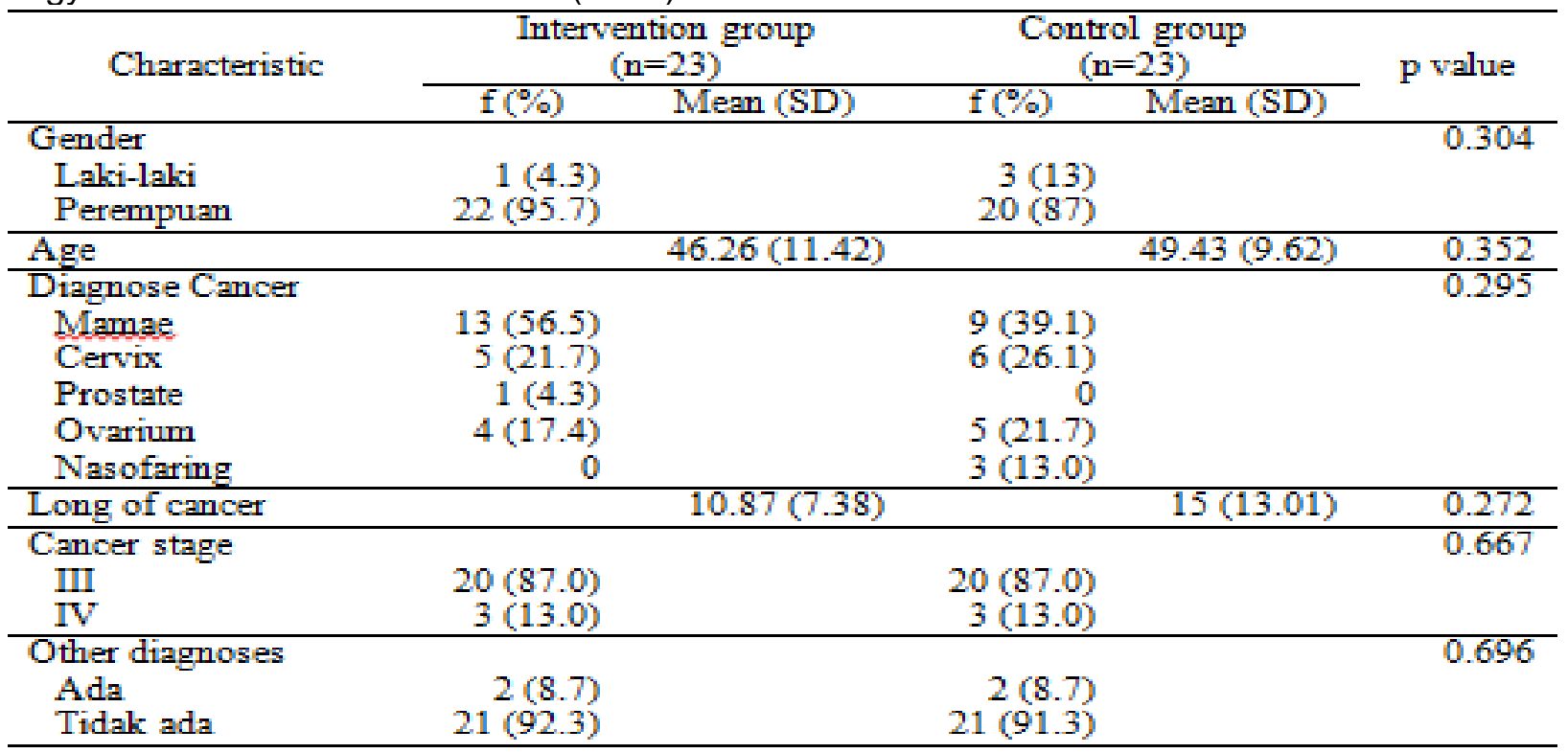

Sumber : Data primer, 2012

Berdasarkan tabel diketahui bahwa sebagian besar responden dalam penelitian ini berjenis kelamin perempuan yaitu sebesar $95,7 \%$ pada kelompok intervensi dan $87,0 \%$ pada kelompok kontrol. Data tersebut sesuai dengan kriteria inklusi pada penelitian ini bahwa karakteristik penyakit yang menjadi fokus dalam penelitian ini adalah kebanyakan kanker pada wanita. $\mathrm{Hal}$ ini ditunjang dengan banyaknya responden dalam penelitian ini didiagnosa kanker payudara sebesar $56,5 \%$ dan kanker serviks $21,7 \%$ pada kelompok intervensi serta sebesar $39,1 \%$ kanker payudara dan $26.1 \%$ kanker serviks pada kelompok kontrol. Berdasarkan uji homogenitas, karakteristik responden pada kelompok intervensi dan kelompok kontrol adalah sama (homogen) baik menurut jenis kelamin $(p=0,301)$, usia $(p=0,352)$, jenis kanker $(p=0,295)$, lama sakit $(p=0,272)$, stadium kanker $(p=0,667)$, dan riwayat penyakit selain kanker $(p=0,696)$ yang berarti kedua kelompok sebanding dan hasil yang didapat dalam penelitian ini tidak dipengaruhi oleh faktor tersebut. 
Tabel 2. Karakteristik Musik Pilihan Responden Kelompok SeLIMuT di IRNA 1 RSUP Dr. Sardjito Yogyakarta Bulan November $2012(n=46)$

\begin{tabular}{ccc}
\hline & Frekuensi (F) & Prosentase (\%) \\
\hline Religi & 7 & 30,43 \\
Dangdut & 0 & 0 \\
Indonesian Pop & 2 & 8,70 \\
Western Pop & 0 & 0 \\
Campursari & 3 & 13,04 \\
Kenangan & 0 & 0 \\
Keroncong & 1 & 4,35 \\
Instrumental & 1 & 4,35 \\
More genre & 9 & 39,13 \\
\hline Jumlah & $\mathbf{2 3}$ & $\mathbf{1 0 0}$ \\
\hline
\end{tabular}

Responden pada kelompok SeLIMuT memilih lagu yang telah disediakan oleh peneliti dalam buku menu. Berdasarkan Tabel 2, dapat diketahui bahwa mayoritas responden kelompok SeLIMuT yaitu 9 orang $(39,1 \%)$, memilih lebih dari satu jenis musik untuk didengarkan dalam terapi SeLIMuT. Lagu yang paling banyak didengarkan saat terapi adalah lagu rohani.

Hal ini membuktikan bahwa jenis musik rohani dan campursari menjadi pilihan terapi sebagian besar responden dalam penelitian ini. Hal ini sesuai dengan penelitian sebelumnya yang menyatakan bahwa seseorang yang sedang sakit parah atau dalam kondisi kronis yang mengakibatkan dirinya tidak dapat berfungsi seperti biasanya akan cenderung mendekatkan diri terhadap agamanya (Harington., Kirjavainen., Teng \& Sullivan, 2001). Intervensi SeLIMuT merupakan terapi yang bertujuan memberikan manfaat relaksasi pada pasien kanker paliatif dengan status hemodinamik menjadi salah satu indikatornya. Berdasarkan Tabel 3, terdapat perbedaan yang signifikan rerata sistolik $(p=0,001)$, diastolik $(p=0,024)$ dan denyut nadi $(p=0,001)$, signifikan jika $\mathrm{p}<0,05$. Penurunan sistolik, diastolik dan nadi pada kelompok SeLIMuT setelah mendapat intervensi dengan nilai mean (SD) secara berurutan 2,50 (3,034); 2,07 $(4,765) ; 0,525(0,285)$.

Tabel 3. Hasil Uji Beda Skor Selisih Nilai Pre Post Sistolik, Diastolik dan Nadi pada Kelompok SeLIMuT dan Kelompok Kontrol di IRNA 1 RSUP Dr. Sardjito Yogyakarta bulan November 2012 $(n=64)$

\begin{tabular}{|c|c|c|c|c|c|c|c|}
\hline \multirow[b]{2}{*}{ Haemodynamic } & \multicolumn{3}{|c|}{ SeLIMuT Group $(n=23)$} & \multicolumn{3}{|c|}{ Control Group $(n=23)$} & \multirow[b]{2}{*}{$P$ value } \\
\hline & $\begin{array}{l}\text { Mean } \\
\text { (SD) }\end{array}$ & $\begin{array}{l}\text { Med } \\
(\min -\max )\end{array}$ & $95 \% \mathrm{Cl}$ & Mean (SD) & $\begin{array}{l}\text { Med } \\
(\min -\max )\end{array}$ & $95 \% \mathrm{Ci}$ & \\
\hline Systolic & $\begin{array}{l}2.67 \\
(3.034)\end{array}$ & $\begin{array}{l}2.50 \\
(-3-8)\end{array}$ & $\begin{array}{l}1.36 \\
3.99\end{array}$ & $\begin{array}{l}-1,03 \\
(1,542)\end{array}$ & $\begin{array}{l}0,00 \\
(-6-0)\end{array}$ & $\begin{array}{l}-1.70 \\
-0.37\end{array}$ & 0,001 \\
\hline Diastolic & $\begin{array}{l}2.07 \\
(4.765)\end{array}$ & $\begin{array}{l}1.50 \\
(-5-11)\end{array}$ & $\begin{array}{l}0.00, \\
4.13\end{array}$ & $\begin{array}{l}-0,11 \\
(1,550)\end{array}$ & $\begin{array}{l}0,00 \\
(-3-5)\end{array}$ & $\begin{array}{l}-0.78, \\
0.56\end{array}$ & 0,024 \\
\hline Heart Rate & $\begin{array}{l}0.525 \\
(0.285)\end{array}$ & $\begin{array}{l}0.602 \\
(0.0-1.1)\end{array}$ & $\begin{array}{l}0.387, \\
0.663\end{array}$ & $\begin{array}{l}-0,170 \\
(0,129)\end{array}$ & $\begin{array}{l}-0.124 \\
(-.03-0.0)\end{array}$ & $\begin{array}{l}-0.331 \\
-0.009\end{array}$ & 0,001 \\
\hline
\end{tabular}

Sumber : Data primer, 2012 
Terjadi penurunan sebesar 3,70 $\mathrm{mmHg}$ pada sistolik, 2,18 $\mathrm{mmHg}$ pada diastolik, dan 0,52 pada nadi, sedangkan pada penelitian sebelumnya dikatakan bermakna secara klinis jika perubahan sebesar $>10 \mathrm{mmHg}$ pada sistolik dan diastolik dan $>4 \mathrm{x} /$ menit pada nadi.
Perbedaan nilai sistolik pre-post pada kelompok kontrol cenderung tetap, sedangkan pada diastolik dan nadi menunjukkan peningkatan dengan mean (SD) secara berurutan $-0,11(0,371) ;-1,84$ $(0,222)$.

Berikut grafik perubahan yang terjadi berdasarkan selisih rerata nilai pre post sistolik, diastolik dan nadi antara kelompok SeLIMuT dan kelompok kontrol.

Gambar 1. Grafik rerata selisih sistolik pre-post kelompok intervensi dan control

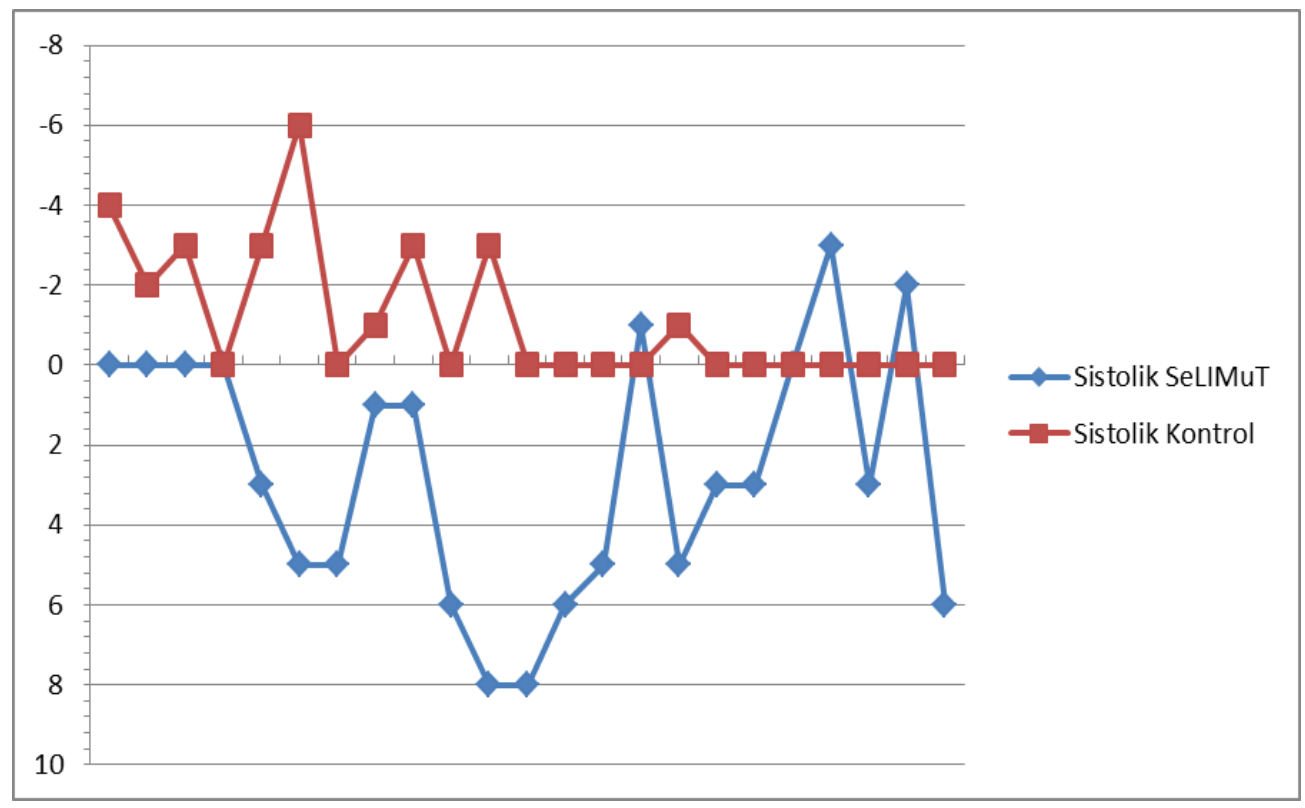

Gambar 2. Grafik rerata selisih diastolik pre-post kelompok intervensi dan control

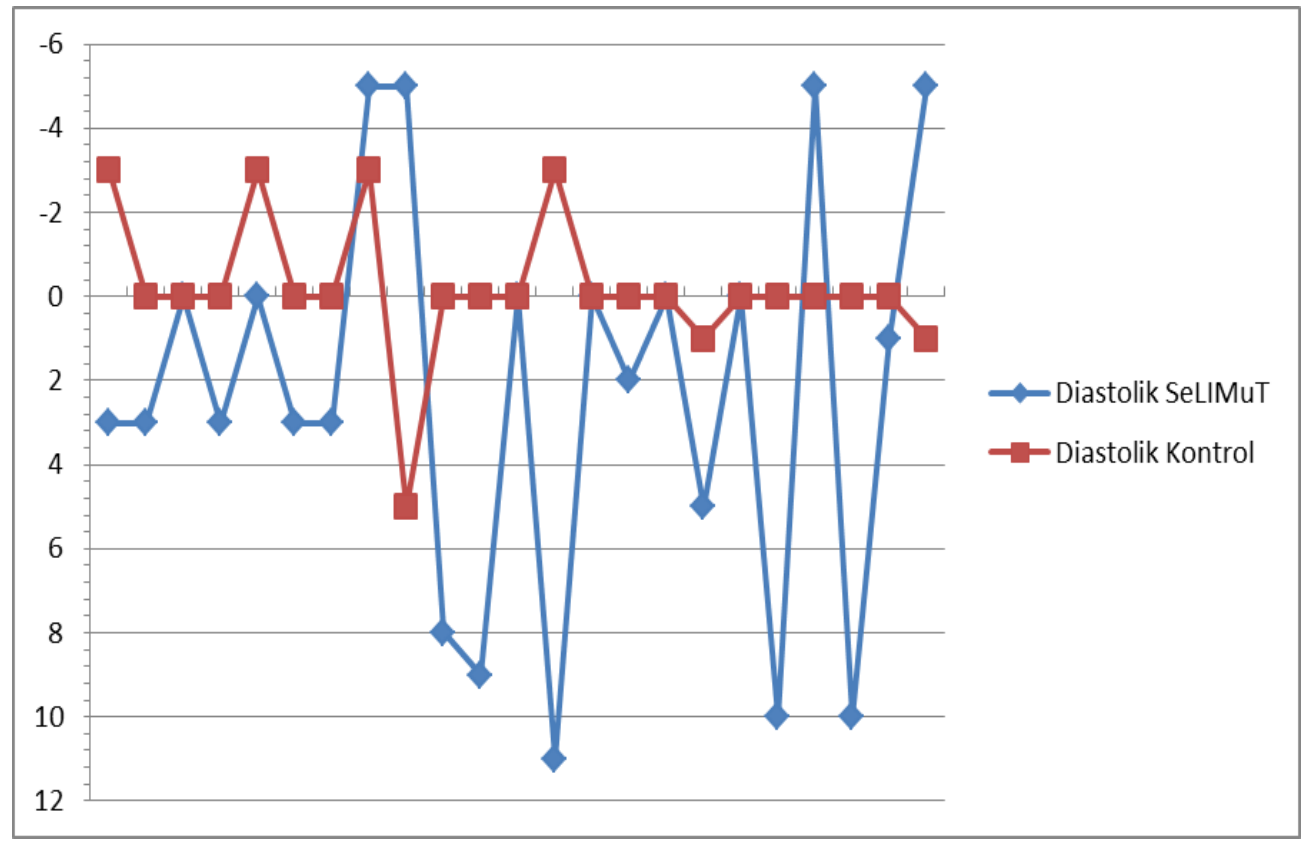


Gambar 3. Grafik rerata selisih nadi pre-post kelompok intervensi dan kontrol

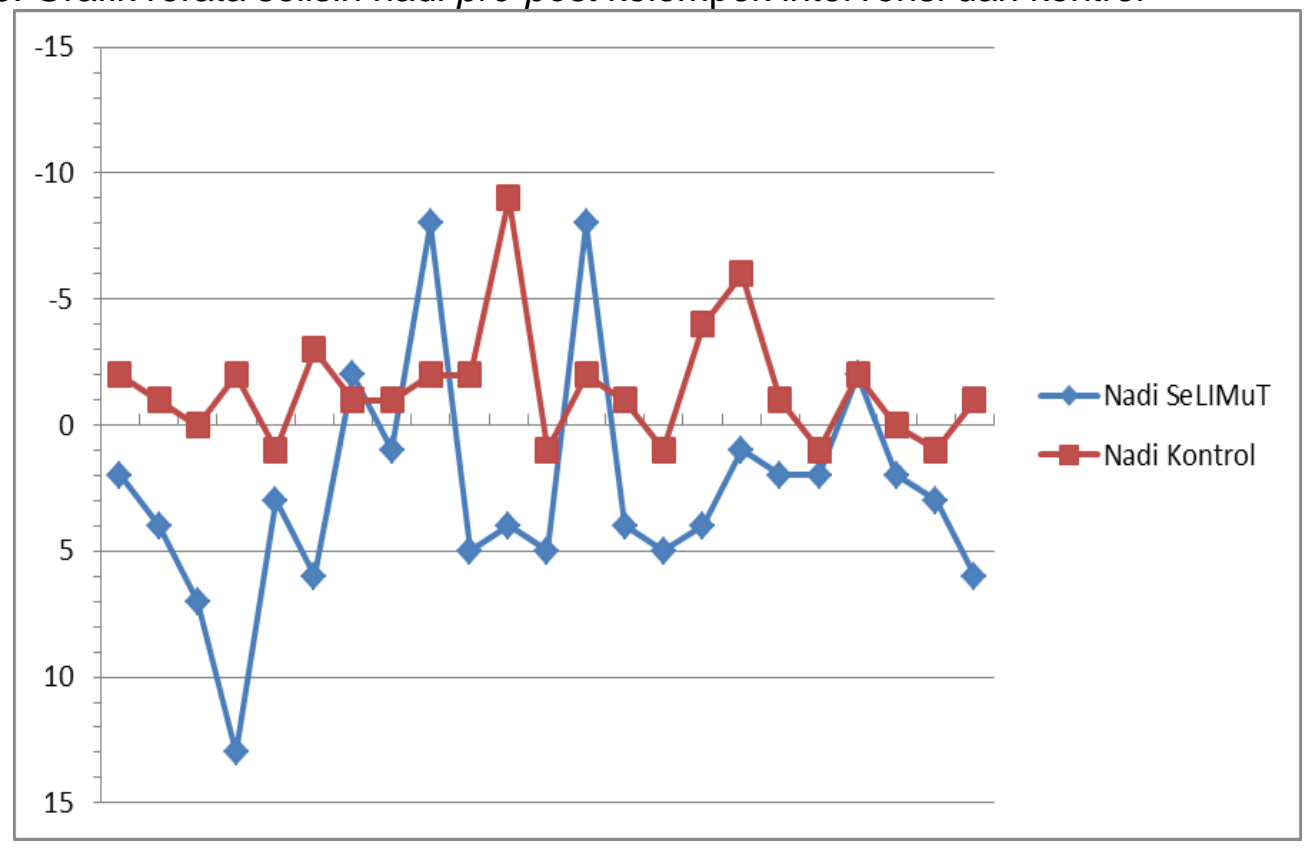

Berdasarkan grafik perubahan selisih sistolik, diastolik dan nadi pre-post antara kelompok SeLIMuT dan kontrol menunjukkan penurunan grafik pada kelompok yang mendapat terapi SeLIMuT. Sedangkan pada kelompok yang tidak mendapat terapi SeLIMuT cenderung tetap dan bahkan mengalami peningkatan. Pada grafik kelompok kontrol menunjukkan selisih bernilai negatif. Nilai negatif pada grafik di atas menjelaskan bahwa nilai post lebih besar dari pada nilai pre, sehingga pengurangan pre-post bernilai negatif

\section{PEMBAHASAN}

Penelitian ini dilakukan untuk mengetahui pengaruh SeLIMuT terhadap status hemodinamik pasien kanker paliatif. Hasil penelitian secara statistik menunjukkan bahwa ada pengaruh SeLIMuT terhadap status hemodinamik pasien kanker paliatif. Pengaruh tersebut berupa penurunan rerata sistolik, diastolik dan denyut nadi pada kelompok yang mendapat intervensi SeLIMuT, sedangkan pada kelompok yang tidak diberi terapi pada sistolik cenderung tidak ada perubahan atau tetap pada diastolik dan nadi justru terjadi peningkatan. Hal ini berarti SeLIMUT memiliki pengaruh positif dalam meningkatkan relaksasi pasien kanker paliatif.

Namun hasil tersebut belum bermakna secara klinis, hal ini mungkin karena post $>$ pre. Sedangkan pada kelompok SeLIMuT bernilai positif yang berarti nilai post lebih rendah dari nilai pre. Berdasarkan hasil yang disajikan di atas, diketahui bahwa secara statistik SeLIMuT berpengaruh positif terhadap status hemodinamik pasien kanker paliatif. Pengaruh tersebut berupa menurunkan rerata sistolik, diastolik dan nadi pada kelompok yang mendapat terapi SeLIMuT, namun hasil tersebut tidak bermakna secara klinis.

disebabkan karena kurangnya dosis dan frekuensi terapi dimana peneliti hanya melakukan dua kali dalam sehari dan dengan rentang waktu yang terlalu panjang. Selain itu kesulitan dalam mengontrol faktor lingkungan pasien seperti suara dan lalu lalang yang berasal dari pasien lain dan keluarga juga mempengaruhi efektifitas terapi SeLIMuT. Mengingat penelitian yang dilakukan sebagian besar berada pada setting bangsal kelas 3 yang diisi sekitar 6 pasien sehingga kurang optimalnya kontrol suara selain suara yang berasal dari terapi SeLIMuT itu sendiri.

Secara teori dipandang dari segi medis, musik memiliki efek yang menguntungkan terhadap tubuh dan psikis (Peretz, 2001). Terapi musik memiliki tujuan untuk membantu pasien dalam mengekspresikan perasaan, membantu rehabilitasi fisik, memberi pengaruh positif 
terhadap kondisi suasana hati dan emosi, meningkatkan memori, serta menyediakan tempat yang unik untuk berinteraksi dan membangun kedekatan emosional (Purwanto., Sumarni \& Sutono, 2008).

SeLIMuT berperan dalam meningkatkan relaksasi pasien melalui rangsangan yang diterima seseorang saat mendengarkan musik yaitu bermula dari indra auditorika yang kemudian secara perlahan akan menstimulasi korteks serebri dan disalurkan melalui sistem sensor atau langsung ke sistem limbik yang pada dasarnya memiliki peranan besar pada respon emosional dari seseorang (Lane., Kasian., Owens \& Marsh, 1998). Dengan demikian, getaran suara musik memulai rantai peristiwa di mana batang otak menyampaikan pesan ke sistem aktivasi retikuler, merangsang perubahan seperti relaksasi otot, penurunan tekanan darah, dan penurunan tingkat pernapasan dan denyut nadi (Bernardi., Porta., \& Sleight, 2006).

Ketika relaksasi stimulasi sistem limbik otak oleh musik akan menurunkan produksi epinephrine (adrenaline) dan norepinephrine. Hormon tersebut dipicu oleh stimulasi pada autonomic nervous system (ANS) dimana hypothalamus berperan sebagai pusat pengaturnya. Kedua hormon ini mengakibatkan peningkatan aliran darah ke otot, detak jantung, dilatasi pembuluh darah, dan bersama kortisol berperan meningkatkan simpanan glikogen ke otot (Bernardi., Porta \& Sleight, 2006).

Dengan mendengarkan musik maka produksi epinephrine dapat dihambat dengan mempengaruhi organ amygdala sebagai pusat reaksi emosi dan perasaan (Bernardi., Porta., \& Sleight, 2006). Amygdala memiliki aktivitas timbal balik dengan hypothalamus melalui jalur striae terminalis, sehingga perangsangan apapun pada aktivitas amygdala akan menyebabkan perangsangan aktivitas hypothalamus (Phipps., Carroll\& Tsiantoulas, 2010).

Penurunan rerata tekanan darah dan denyut nadi pada kelompok SeLIMuT dapat dipengaruhi oleh beberapa hal. Dalam penelitian ini, penurunan dapat terjadi karena responden menyukai musik, responden memilih sendiri musik yangakan digunakan dalam terapi, waktu pemberian terapi bertepatan dengan waktu senggang responden, durasi terapi SeLIMuT dianggap sesuai oleh responden, dan responden dapat bebas berekspresi saat mendengarkan musik.

Karakteristik SeLIMuT yang membedakan terapi ini dengan terapi musik yang biasanya telah dilakukan yaitu adanya kebebasan individu untuk memilih sendiri musik yang akan didengarkan selama terapi. Kebebasan memilih musik diduga dapat menjadi faktor yang mempengaruhi efektifitas SeLIMuT dalam meningkatkan rasa nyaman dan relaksasi pasien.

Jenis musik yang digunakan dalam SeLIMuT juga menjadi pendukung terciptanya rasa nyaman dan relaksasi pasien. SeLIMUT menggunakan musik slow dengan tempo stabil, level suara yang rendah dan soft dynamic, tekstur yang konsisten (kombinasi suara dan instrumental) dan harmoni yang sederhana.

Musik yang lembut (dengan pitch dan volume terkontrol), familiar, efektif dan disukai oleh pasien lebih bermanfaat meningkatkan relaksasi dibandingkan dengan musik baru yang asing dan rumit (Djohan, 2010; Wigram., Pedersen \& Bonde, 2002). Musik yang dipilih juga memiliki unsur ketenangan bagi pasien misalnya musik-musik yang berirama rohani agar pasien merasa dekat dengan Tuhan sehingga hal tersebut mampu mengurangi stress yang dihadapi (Abdillah \& Saleh, 2010). Hal ini juga yang menyebabkan sebagian besar responden yang mendapat terapi SeLIMuT memilih jenis musik religi sebagai musik pilihan terapi.

Waktu pemberian SeLIMuT yaitu sekitar pukul 15.00 WIB dan 19.00 WIB selama dua hari untuk satu responden. Waktu ini sudah disesuaikan dengan kondisi di lapangan. Pelaksanaan terapi SeLIMuT tidak akan mengganggu aktivitas tim kesehatan maupun pasien. Pasien mengatakan bahwa waktu pemberian SeLIMuT bertepatan dengan waktu senggang mereka.

Belum ada penelitian yang meneliti waktu yang pas untuk mendapatkan terapi musik. Waktu pemberian terapi musik dapat bervariasi, bahkan intensitas pemberian terapi music pun juga begitu bervariasi (Greer, 2007; Tzu-Huang., Good \& Zauszniewski, 2010). Ada yang memberikan terapi musik satu kali dalam 
satu minggu (Loomba., Shah., Chandrasekar., Arora \& Molnar, 2012), bahkan ada yang memberikan terapi musik dua sampai tiga kali dalam satu hari (Green \& Hertin, 2004). Berdasarkan semua fenomena yang telah dijabarkan di atas dapat disimpulkan bahwa mendengarkan musik memiliki banyak efek yang positif dalam proses penyembuhan. Pada proses penyembuhan reaksi psikologis seperti rasa nyeri dan tidak nyaman akibat penyakit, kecemasan serta ketakutan akan penyakit akan menstimulasi saraf simpatis yang erat hubungannya dengan peningkatan tekanan darah dan frekuensi denyut jantung yang merupakan komponen dari hemodinamik (American Cancer Society, 2011; Nillson, 2009; Berger., Portenoy., \& Weissman, 2002). Kondisi tersebut akan menurunkan optimalisasi proses pengobatan pasien kanker, dikatakan bahwa pasien yang tegang dan cemas yang disertai peningkatan tekanan darah dan frekuensi detak jantung lebih banyak merasakan nyeri selama perawatan berlangsung dibanding

\section{KESIMPULAN DAN SARAN}

Intervensi SeLIMuT dengan
karakteristik pilihan pasien, intervensi
bertepatan pada waktu senggang pasien,
dan dengan menggunakan jenis musik yang
slow, tempo stabil, level suara rendah, soft

\section{DAFTAR PUSTAKA}

Abdillah, N., Saleh, E. (2010). Pengaruh musik Mozart. Mutiara Medika. 10(1):22-28.

American Cancer Society. (2011). Cancer Facts and Figures 2011. American Cancer Society, Inc; 2011.

Berger, Ann, M., Portenoy, Russel, K., Weissman, David, E., (2002). Principles and Practice of Palliative Care and Supportive Oncology. $2^{\text {nd }}$ ed. Lippincott Williams \& Wilkins Publisher.

Bernardi, L., Porta, C., Sleight, P., (2006). Cardiovascular, cerebrovascular, and respiratory changes induced by different types of music in musicians and nonmusicians: the importance of silence. Heart. 92(4) 445-452.

Burns., S, Harbuz M, Hucklebridge, Bunt., L. (2001). A pilot study into the therapeutic effects of music therapy at a cancer help center. Alternative pasien yang rileks (Halim, 2007; Hodges,. et al, 2005). Oleh karena itu, musik merupakan sebuah terapi yang sesuai dan efektif dalam meningkatkan relaksasi dan kenyamanan yang ditunjukkan dengan status hemodinamik yang baik khusunya yang terjadi pada pasin kanker paliatif.

Penelitian ini menunjukkan bahwa terapi SeLIMuT efektif diterapkan dalam meningkatkan efek relaksasi yang ditandai dengan menurunnya tekanan darah dan denyut jantung secara signifikan pada pasien kanker paliatif. Responden yang menerima terapi musik banyak menunjukkan respon yang positif pada sisi psikologi seperti hilangnya perasaan terancam karena penyakit dan ketegangan (Bernardi., Porta \& Sleight, 2006). Efek respon positif pada aspek positif yang ditunjukkan kebanyakan pada responden adalah menghilangnya ekspresi ketakutan, berkurangnya ketegangan otot dan perasaan kelelahan (Krout, 2007; Wigram., Pedersen \& Bonde, 2002).

dynamic, dan tekstur konsisten efektif meningkatkan relaksasi pasien yang ditandai dengan penurunan nilai rerata sistolik, diastolik, dan denyut nadi secara statistik, namun perbedaan tersebut belum dikatakan bermakna secara klinis.

Therapies in Health and Medicine. $7(1): 48-56$.

Djohan. (2010). Respon Emosi Musikal. Bandung: Lubuk Agung.

Effendy, C., Engels, Y., Osse, Bart, H.P., Tejawinata, S., Vissers, K., VernooijDassen, M. (2011). Problem and Needs pada pasien kanker di Indonesia dan di Netherlands. Proceedings of Seminar Palliative Care Program Studi IImu Keperawatan Fakultas Kedokteran Universitas Gadjah Mada. Yogyakarta.

Green, W.C., Hertin, S. (2004). Terapi Alternatif. Yogyakarta: Yayasan Surviva Paski.

Greer, S. (2007). The Effects of Music on Pain Perception. Available from http://hubel.sfasu.edu/courseinfo/SLO3/ music_therapy.htm 
Halim, Samuel. (2007). Efek Mozart dan Terapi Musik Dalam Dunia Kesehatan. Mutiara Medika. 29(1)2010;30-34.

Harington, C. Kirjavainen, A. Teng, Sullivan, (2001). Cardiovasculer Responses To Three Simple Provocative Test Autonomic Activity in Sleeping Infants. Journal Appl Physiol. Vol. 91 Agustus 2001. www.jap.org

Hodges, R.K,. et al,. (2005). Real World Nursing Survival Guide Haemodynamic Monitoring. St Louis : Elsevier Saunders. 150-168.

Kaliyaperumal, R., Subash, JG. (2010). Effect of music therapy for patients with cancer pain. International Journal of Biological and Medical Research.1(3):79-81.

Krout, R.R. (2007). Music listening to facilitate relaxation and promote wellness : Integrated aspects of our neurophysiological responses to music. The Arts in Psychotherapy. 34:134-141.

Lane, J. D., Kasian, S. J., Owens, J. E. \& Marsh, G. R. (1998). Binaural Auditory Beats Affect Viggilance Performance and Mood. Reprint Physiology and Behavior. Elvier Science Inc.

Loomba, R.S., Shah, P.H., Chandrasekar, S., Arora, R., Molnar, J. (2012). Effects of Music on Systolic Blood Pressure, Diastolic Blood Pressure, and Heart Rate: a Meta-analysis. Indian Heart Journal. 309-313.

Nillson, U,. (2009). The Effect of Music Intervention in Stress Response to Cardiac Surgery in a Randomized Control Trial. Sweden: Department of Cardiothoracic Surgery and Center for Health Care Sciences Orebo University Hospital. 38:201-207.

Peretz, I. (2001). Listen to the Brain: A Biological Perspective on Music and Emotion In: Sloboda, J. A. \& Juslin, P. N. (Eds.). Music and Emotion: Theory and Research. NY: Oxford University Press.

Phipps, M.A., Carroll, D.L., Tsiantoulas, A., (2010). Music as a Therapeutic Intervention on an Inpatient Neuroscience Unit. Complementary Therapies in Clinical Practice. Elsevier: 15:138-142.

Purwanto, E., Sumarni, D.W., Sutono. (2008). Efek musik terhadap perubahan intensitas nyeri pada pasien post operasi. Jurnal Ilmu Keperawatan, 3(2):110-115

Smeltzer, S.C. (2002). Buku Ajar Keperawatan Medikal Bedah Brunner dan Suddarth. $8^{\text {th }}$ rev.ed. Jakarta : EGC.

Stanczyk, M.M. (2011). Music Therapy in Supportive Cancer Care. Reports of Practical Oncology and Radiotherapy. $\mathrm{x}$ $x \mathrm{x}: \mathrm{xxx}-\mathrm{x} x \mathrm{x}$

Thompson, A.H., Grocke, D. (2007). The Effect of Music Therapy on Anxiety in Patients who are Terminally III. Journal of Palliative Medicine: Mary Ann Liebert, Inc. 11(4):189-193

Tzu-Huang, Shih; Good, Marion; Zauszniewski. (2010). The effectiveness of music in relieving pain in cancer patients : A randomized controlled trial. International Journal of Nursing Studies 47:1354-1362.

Wigram, T., Pedersen, I.N., \& Bonde, O.L. (2002). A Comprehensive Guide to Music Therapy: Theory, Clinical Practice, Research and Training. London: Jessica Kingsley Publishers.

Zhang, J. (2007). Effect of Age and Sex on Heart Rate Variability in Healthy Subject. Journal of Manipulative Physiologic Therapy. (30); 374379.Publishers. 